\title{
Changes in Total Phenolic and Protein Contents during Production of Protein Isolates from Carica papaya (Pawpaw) Seeds
}

\author{
Oseni Kadiri*, Gbadamosi Olasunkanmi Saka, Babatunde Olawoye, Charles Taiwo Akanbi
}

Department of Food Science and Technology, Obafemi Awolowo University, PMB 13, Ile-Ife, Nigeria A R T I C L E I N F O

Article history:

Received 29 September 2015

Accepted 24 October 2016

Available online, ISSN: 2148-127X

\section{Keywords:}

Polyphenols

Carica papaya seeds

Total phenolic content

Protein

Pearson correlation test

Processing

\section{A B S T R A C T}

The effect of different processing stages- defatting, solubilization, isoelectric precipitation, neutralisation and lyophilisation on the total phenolic content and protein content of Carica papaya (pawpaw) seeds (CPS) full-fat flour (CFF), defatted flour (CDF), protein concentrates (CPC) and protein isolates (CPI) was studied. The folinciocalteu procedure was used to assess the total phenolic concentrations of the Carica papaya products and results were expressed as gallic acid equivalent (GAE). Optimal protein content was estimated at $\mathrm{pH} 10$ for all samples. Higher levels of polyphenols were extracted using water-methanol (20/80) mixture compared to $100 \%$ methanol. Total phenolic content (TPC) was demonstrated in a trend of CDF > CPC > CFF > CPI with CDF having the highest TPC. The finding suggested a more economical protein isolate production method. The study concludes that the processing of CPS into the various products (CFF, CDF, CPC \& CPI) improves its protein and polyphenol content.

${ }^{*}$ Corresponding Author:

E-mail: kadirioseni@yahoo.com

\section{Introduction}

Pawpaw (Carica papaya) is a tropical evergreen fruit which belongs to the Caricaceae family. It is believed to have originated from the southern part of Mexico and Central America but now widely distributed in the subtropical region of Africa. Carica papaya seeds are found in the fruit of the plant (Kadiri, 2015). It is a by-product of industrial utilisation as well as domestic consumption. Its polyphenol compounds have been associated with the cure and prevention of illness related to oxidative damages to tissues. It has been used as a medicinal plant since ancient time (Jaime et al., 2007). Dwikat et al. (2010) reported that aqueous extracts of Carica papaya seeds had an anti-apoptotic effect due to its antioxidant activity. Zhou et al. (2011) showed that ethyl acetate fractions from papaya seeds had strong 2,2-diphenyl-1picrylhydrazyl (DPPH) and hydroxyl free radical scavenging activities. They also subjected the ethyl acetate fraction of Carica papaya seeds to column chromatography, to yield two phenolic compounds, phydroxybenzoic acid and vanillic acid which possessed significant antioxidant activities. Phenolic compounds are a diverse group of plant secondary metabolites which comprises of aromatic rings, bearing one or more hydroxyl substituents which range from simple phenolic molecules like phenol to highly polymerised compounds often referred to as polyphenols (Iyawe and Azih, 2011). Plant phenolic compounds, and their secondary metabolites such as flavonoids and proanthocyanidins, have been reported as the bioactive components associated with the antioxidant properties and health benefits of plants (Kadiri and Olawoye, 2016; Pierson et al., 2012). Phenolic compounds from plants have been reported to be beneficial to human health due to their antioxidant properties (Kadiri and Olawoye, 2016; Quad et al., 2011; Tsao, 2010; Visioli et al., 2011). Furthermore, previous in-vitro and in-vivo studies have linked plant polyphenols with health benefits as stated earlier (Kadiri and Olawoye, 2015; Visioli et al, 2011; Vuong, 2012). Processing methods such as cooking have been associated with the destruction of phenolic compounds. For example, Yu-Wei and Wang (2015) reported that cooking lowered the total phenolic content of germinated pulses by $12-51 \%$ and antioxidant activity by $16-67 \%$.

The growing demand for low cost and non-genetically modified vegetable proteins has pushed the food industry to explore alternate sources of protein. Processing of CPS into products with good nutritional and functional properties can help in increasing the usefulness and its utilisation. The aims of this research are to process the Carica papaya seeds into products rich in protein and to study the changes in total phenolic and protein contents during processing. 


\section{Materials and Methods}

Carica papaya Linn. fruits were collected at various sections of the premises of Obafemi Awolowo University, Osun State, Nigeria between the months of October December 2014 and identified by the Botany and Crop Science Department of the same university. The fruits were split open and the seeds de-coated by rubbing briskly with a grater. De-coated seeds were washed with tap water to remove extraneous materials, and the clean seeds obtained were oven dried in a Gallenkamp oven (OVB 305, United Kingdom) at $60^{\circ} \mathrm{C}$ for $12 \mathrm{hr}$. The dried seeds were milled using Kenwood grinder and sieved through a $300 \mu \mathrm{m}$ sieve (Endecott's sieve, United Kingdom). The sieved flour was packaged using an air tight container and stored at room temperature until use.

Preparation of Carica papaya seeds defatted flour, concentrates and isolates

Carica papaya seeds defatted flour was prepared using the method of Sathe (1994) and Gbadamosi et al. (2012). Carica papaya seeds protein concentrate (CPC) was prepared by a modification of the method described by Cheftel et al. (1985). Flour to water ratio of 1:20 was stirred on a magnetic stirrer for $10 \mathrm{~min}$, and $\mathrm{pH}$ of the resultant slurry was adjusted to 4.0 and centrifuged at $4000 \mathrm{~g}$ for $30 \mathrm{~min}$. The precipitate was washed twice with distilled water, adjusted to $\mathrm{pH} 7.0$, centrifuged at $4000 \mathrm{~g}$ for $30 \mathrm{~min}$ and then dried in an oven at $45^{\circ} \mathrm{C}$ for $8 \mathrm{hr}$ to recover the protein concentrate.

Carica papaya protein isolates were prepared by the method described by Chavan et al. (2001) and as modified by Gbadamosi et al. (2012). Flour to water ratio of 1:10 was stirred on a magnetic stirrer for $20 \mathrm{~min}$, and the $\mathrm{pH}$ of the medium was adjusted to $\mathrm{pH} 10.0$ and stirred for $4 \mathrm{hr}$ at constant $\mathrm{pH}$. The slurry was centrifuged (Bosch, TDL-5, United Kingdom) at $4000 \mathrm{~g}$ for $30 \mathrm{~min}$ and the supernatant was collected and filtered through a Whatman No. 1 filter paper. The supernatant was adjusted to $\mathrm{pH}$ 4.0, and the mixture was centrifuged as above. The precipitate was washed twice with distilled water, and then re-suspended in distilled water, adjusted to $\mathrm{pH} 7.0$ and freeze-dried to obtain the Carica papaya protein isolate (CPI). The chart for this process is as shown in Figure 1.

\section{Yield of Protein Isolates}

The yields of protein isolate (PI) samples were calculated based on the weights of CPI and defatted flour on the dry basis.

$$
\begin{aligned}
& \text { YPI }=\frac{\text { Weight of protein isolate }(g)}{\text { Weight of flour }(g)} \times 100 \\
& \text { YPI }=\text { Yield of protein isolate }(\%)
\end{aligned}
$$

\section{Protein Recovery}

Protein contents of the defatted flour and protein isolate were used in calculating the protein recovery by using the following formula:

$$
\begin{aligned}
\mathrm{PR} & =\frac{\text { PI Wt. }(g) \times \text { PI protein contents }(\%)}{\text { Flour } W t .(g) \times \text { Flour protein contents }(\%)} \times 100 \\
\mathrm{PR} & =\text { Protein Recovery }(\%)
\end{aligned}
$$

Quantification of Proteins at Varying $p H$

Sample preparations: The effect of $\mathrm{pH}$ on protein content was determined by a method described by Gbadamosi et al. (2012) with modifications. Sample (2.5 g) was dispersed in $250 \mathrm{ml}$ of $0.1 \mathrm{M} \mathrm{NaOH}$. The mixture was stirred on a magnetic stirrer (Cenco, Netherland) for $1 \mathrm{hr}$, centrifuged (Harrier 15/80 MSE) at $4500 \mathrm{~g}$ for 30 min and then filtered through Whatman No.1 filter paper.

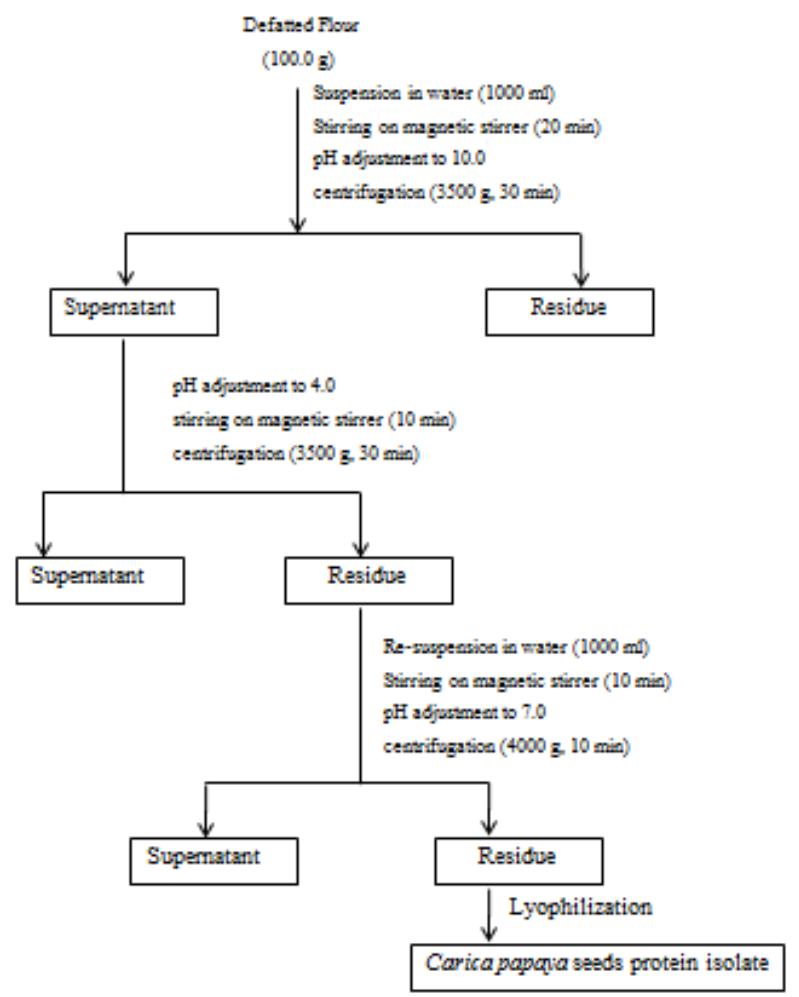

Figure 1. Scheme for the production of Carica papaya seed protein isolate. Adapted from Chavan et al. (2001)

An aliquot of the filtrate was centrifuged at $12000 \mathrm{~g}$ for $20 \mathrm{~min}$ and the resulting filtrate obtained was labelled supernatant A. Supernatant A contain the protein content of the samples at neutral $\mathrm{pH}$. The remaining filtrate was divided into $20 \mathrm{ml}$ portions and the $\mathrm{pH}$ of each portion was adjusted to $\mathrm{pH} \mathrm{2,4,6,8}$ and 10 with $1 \mathrm{M} \mathrm{HCl}$ or $\mathrm{NaOH}$. The solution was then made up to $30 \mathrm{ml}$ and stirred for another $10 \mathrm{~min}$. An aliquot of each mixture was also centrifuged at $12000 \mathrm{~g}$ for $20 \mathrm{~min}$ and the centrifuged solution labelled as supernatant B.

Protein determination by Lowry method: The protein content of supernatant A (neutral $\mathrm{pH})$ and $\mathrm{B}(\mathrm{pH} \mathrm{2,} \mathrm{4,} \mathrm{6,} 8$ and 10) was determined using the modified Lowry method (Markwell et al., 1978). To make up $1 \mathrm{ml}$ of supernatant $\mathrm{A}$ and $\mathrm{B}, 50 \mu \mathrm{l}$ of both were pipetted separately and $950 \mu \mathrm{l}$ of distilled water was added followed by the addition of $3 \mathrm{ml}$ of Lowry's reagent $\mathrm{C}$ (mixture of reagent $\mathrm{A}$ and $\mathrm{B}$ at the ratio of 100 to1; Reagent A: $2 \% \quad \mathrm{Na}_{2} \mathrm{CO}_{3}, 0.4 \% \mathrm{NaOH}, 0.16 \%$ Sodium 
chloride, $1 \%$ sodium dodecyl sulphate dissolved in distilled water; Reagent B: $4 \% \mathrm{CuSO}_{4} \cdot 5 \mathrm{H}_{2} \mathrm{O}$ dissolved in distilled water) and incubated at room temperature for 1 hr. Also, $0.3 \mathrm{ml}$ of Folin Ciocateu phenol reagent (1 part of Folin Ciocalteu phenol with 3 parts of distilled water) was added to all mixtures in test tubes each in triplicates and mixed vigorously using vortex mixer (Vortex Mixer RX3, VELP Scientifica, Italy). The tubes were allowed to stand at room temperature for $45 \mathrm{~min}$ and the absorbance of the mixture was then measured at $600 \mathrm{~nm}$ using a spectrophotometer (722-2000 Spectronic 20 D, England). Bovine serum albumin standard was pipetted $(0.2,0.4$, $0.6,0.8$ and $1 \mathrm{ml}$ ) and made up to $3 \mathrm{ml}$ with distilled water. The procedure described above was then followed. A standard curve was prepared with a linear range of $0-$ $100 \mathrm{mg} / \mathrm{ml}$ using bovine serum albumin as the standard and the result is shown in Figure 2.

\section{Determination of Total Phenolic Content}

The total phenolic content was determined as described by Singleton and Rossi (1965) and Gulcin et al. (2003) with modification.

Sample preparation: Extract for this analysis was prepared by dissolving $25 \mathrm{mg}$ of the samples in $10 \mathrm{ml}$ of methanol. The suspension was stirred on a magnetic stirrer (Cenco, Netherland) for $4 \mathrm{hr}$ and afterwards filtered through Whatman No.1 filter paper to give the absolute methanolic extracts (100\% methanolic extract). This same procedure was used in the preparation of the aqueous methanol extract (80/20: $\left.\mathrm{MeOH} / \mathrm{H}_{2} \mathrm{O}\right)$. The bulk extraction was then used to prepare different concentrations of the extract.

Total phenol estimation: To $1 \mathrm{ml}$ of different concentrations $(0.5,1.0,1.5,2.0$ and $2.5 \mathrm{mg} / \mathrm{ml})$ of the samples or standard (gallic acid) was added $0.2 \mathrm{ml}$ of Folin-Ciocalteu's phenol reagent and the resulting mixture vortexed. After $5 \mathrm{~min}$ of standing, $1.0 \mathrm{ml}$ of $7 \%$ $(w / v)$ saturated $\mathrm{Na}_{2} \mathrm{CO}_{3}$ solution was added. After 2 hours of incubation at room temperature, the absorbance at 750 $\mathrm{nm}$ was measured using water as blank. A standard curve was prepared with a linear range of $0.5-2.5 \mathrm{mg} / \mathrm{ml}$ using gallic acid as the standard. The results were expressed as gallic acid equivalent (GAE) of the sample.

\section{Statistical Analyses}

One-way ANOVA and the LSD post hoc test were conducted using the SPSS statistical software version 20. Differences between the mean levels of the components in the different experiments were taken to be statistically significant at $\mathrm{p}<0.05$. Pearson correlation test was also done using Minitab version 17 software.

\section{Results}

\section{Protein Content}

At neutral $\mathrm{pH}, \mathrm{CPI}$ had the highest protein content of $85.05 \mathrm{mg} / \mathrm{ml}$ which differs significantly $(\mathrm{P}<0.05)$ from CPC (64.14 mg/ml), CDF (54.17 mg/ml) and CFF (27 $\mathrm{mg} / \mathrm{ml}$ ) as shown in Figure 3. Figure 4 shows the protein content of the Carica papaya full-fat flours, defatted flour, protein concentrate and protein isolate at various $\mathrm{pH}(\mathrm{pH} 2-10)$. The lowest protein content for the defatted flour was found to be $5.71 \mathrm{mg} / \mathrm{ml}$ at $\mathrm{pH} \mathrm{4}$, while the protein content was $27 \mathrm{mg} / \mathrm{ml}$ at $\mathrm{pH} 2$. The protein content increased from $\mathrm{pH} 6$ to $\mathrm{pH} \mathrm{10,} \mathrm{and} \mathrm{the} \mathrm{maximum}$ protein content of $35.86 \mathrm{mg} / \mathrm{ml}$ was obtained at $\mathrm{pH} 10$. The same trend was observed for CDF, CPC and CPI.

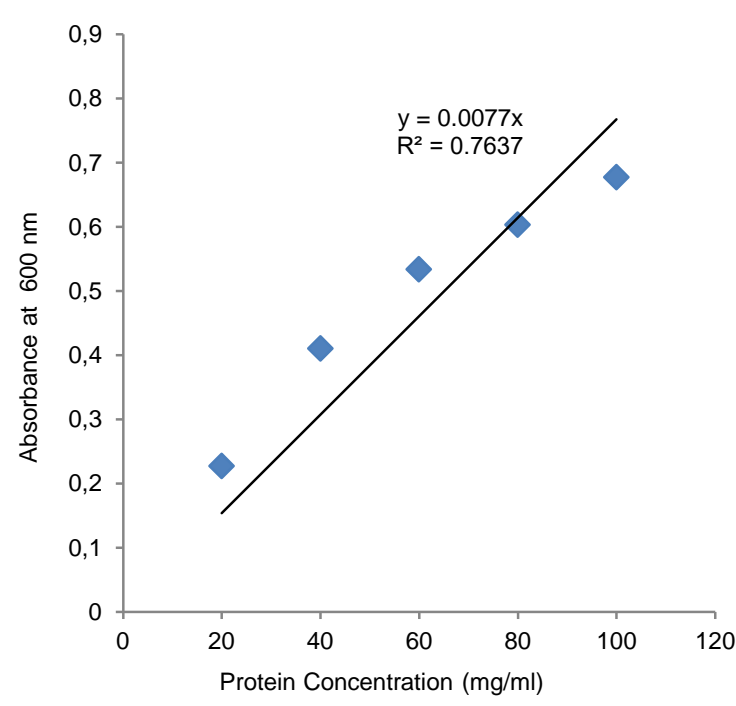

Figure 2 Standard curve for bovine serum albumin

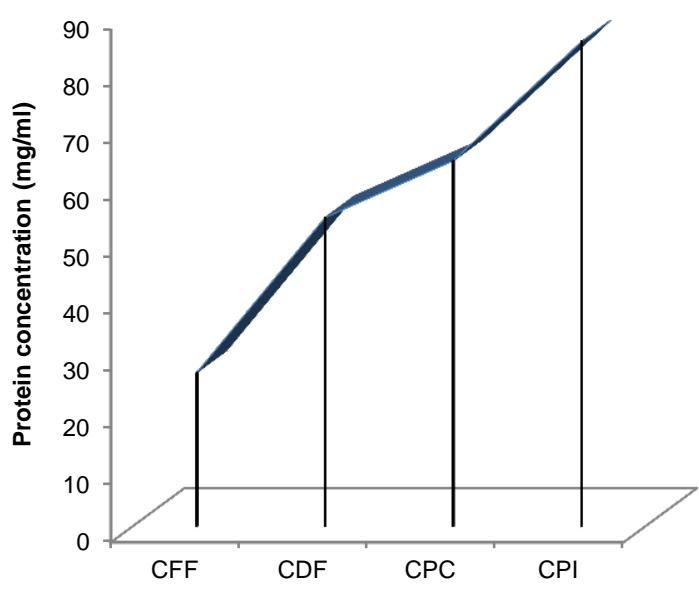

Figure 3 Protein concentration of the Carica papaya fullfat flour (CFF), defatted flour (CDF), protein concentrate (CPC) and protein isolate (CPI) at neutral $\mathrm{pH}$ 

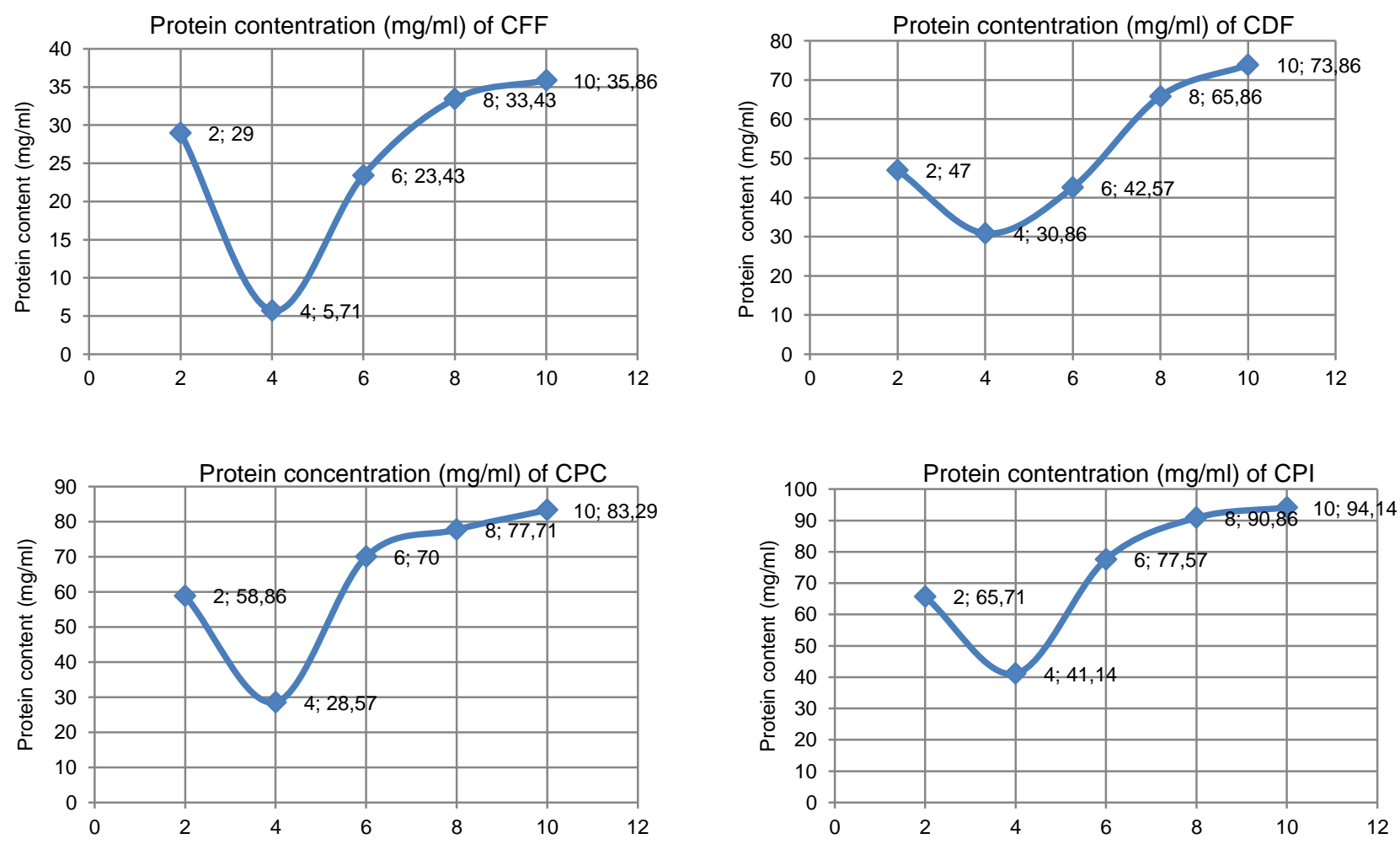

Figure 4 Protein concentration of samples at different pH, CFF: Full-fat flour of Carica papaya seed, CDF: Defatted flour of Carica papaya seed, CPC: Protein concentrates of Carica papaya seed, CPI: Protein isolate of Carica papaya seed

\section{Total Phenolic Content (TPC)}

Total phenolic content of absolute and aqueous methanol fractions of the full fat flour, defatted flour, protein concentrate and protein isolates was determined by using the Folin-Ciocalteu reagent and results were expressed as gallic acid equivalents of extracts. The total phenolic contents of the different sample extracts were calculated using the standard curve of gallic acid $(\mathrm{y}=$ $0.96 \mathrm{x} ; \mathrm{R}^{2}=0.9803$ ) (Figure 5).

The amounts of total phenolic (TPC) for the absolute and aqueous methanolic extracts are presented in Table 1 and Table 2. The TPC of an absolute methanolic extract of the CFF to CPI range from 0.373-0.502 GAE $\mu \mathrm{g} / \mathrm{g}$ and aqueous methanolic extract ranges from 0.721-0.810 GAE $\mu \mathrm{g} / \mathrm{g}$ and differs significantly $(\mathrm{P}<0.05)$ among tested samples. The aqueous methanol extract was contained the highest total amount of phenolic compared to the absolute methanolic fractions. In a comparison of all extracts, the total phenolic content was demonstrated in a trend of $\mathrm{CDF}>\mathrm{CPC}>\mathrm{CFF}>\mathrm{CPI}$.

\section{Discussion}

\section{Protein Composition}

Protein isolate exhibit highest protein content of $88.08 \%$ which differs significantly $(\mathrm{P}<0.05)$ from the protein concentrate $(60.42 \%)$, defatted flour $(32.40 \%)$ and the full-fat flour $(25.18 \%)$. The high protein content of the protein isolate was as a result of the production process which increased the content of protein in the finished

product. The protein content of PI compared well with those of Bambara protein isolates $(85.97 \%)$, heat processed peanut isolates $(84.20 \%)$ and conophor nut protein isolates $(80.00 \%)$ as reported by Eltayeb et al. (2011), Kain et al. (2007) and Gbadamosi et al. (2012), respectively. However, Carica papaya seeds protein isolate had lower protein content than safflower protein isolates $(90.1 \%)$ and heat coagulated mustard protein isolates (95\%) reported by Ulloa et al. (2011) and Alireza and Bhagya (2009), respectively. The significance of this finding is that pawpaw protein isolates might be used in the supplementation of food products with high carbohydrate to protein ratio.

\section{Effect of $\mathrm{pH}$ on the Protein Contents of Carica} Papaya Seeds Fraction and Protein Isolates

Carica papaya seed protein has been reported to exhibit low functionality such as solubility, foam capacity, foam stability, emulsifying activity index and emulsifying stability index at their isoelectric point (pI) (Kadiri, 2015). At pH equal to the protein's pI, the charge repulsions of similar molecules are relatively low and many proteins aggregate to form a complex structure of molecules. There was a clear effect of precipitation $\mathrm{pH}$ on the protein recovery in the CPS fractions and in the protein isolates. The protein recovery and protein contents in the CPS fractions were lower at $\mathrm{pH}$ around 4.0 (Figure 4). Protein recovery in the protein isolates was lower at $\mathrm{pH} 3.0$ and 4.0 as compared to higher $\mathrm{pH}$ points. However, there was no significant difference $(\mathrm{p} \square 0.05)$ in 
protein recovery and protein contents of the protein isolates prepared at $\mathrm{pH}$ range of 4.6-5.0. At the $\mathrm{pH}$ range ( $\mathrm{pH} 4.3-10.0), 53.34-88.08 \%$ of the soluble protein was recovered as protein isolate. The protein recovery was lower than safflower protein isolates $(90.1 \%)$ reported by Ulloa et al. (2011) but higher than the $80.00 \%$ of conophor nut protein isolates reported by Gbadamosi et al. (2012). Protein recovery can be improved by using different precipitation aids such as sodium hexametaphosphate, sodium sulphate and sodium chloride (Jayasena et al., 2006; Ruiz and Hove, 1976; Gbadamosi et al., 2012). Production of CPS protein isolate at a higher $\mathrm{pH}$ level such as $\mathrm{pH} 10.0$ reduces the cost of production as less amount of acid is required at the precipitation step. The high protein contents of CPS protein isolates $(\sim 88.08 \%)$ indicate that the extraction $\mathrm{pH}$ of 10.0 as well as the range of acidic $\mathrm{pH}$ values applied in this study is effective in producing highly concentrated protein isolates. The unfolding of a protein molecule at higher alkaline $\mathrm{pH}$ values than at higher acid $\mathrm{pH}$ value and increase solubility might be responsible for the increasing protein content observed at $\mathrm{pH} 10$. The unfolding of protein molecules is a result of increased intra-molecular electrostatic repulsion caused by the high net charge as $\mathrm{pH}$ increases which were responsible for increased solubility and protein extracted in increasing alkalinity of the extracting medium. This result suggests that extraction of CPS proteins will be best done using an alkaline medium than an acidic medium. Protein isolates with high protein contents are preferable in the food industry since the lesser amount is required to realise desirable nutritional and functional properties in food products.

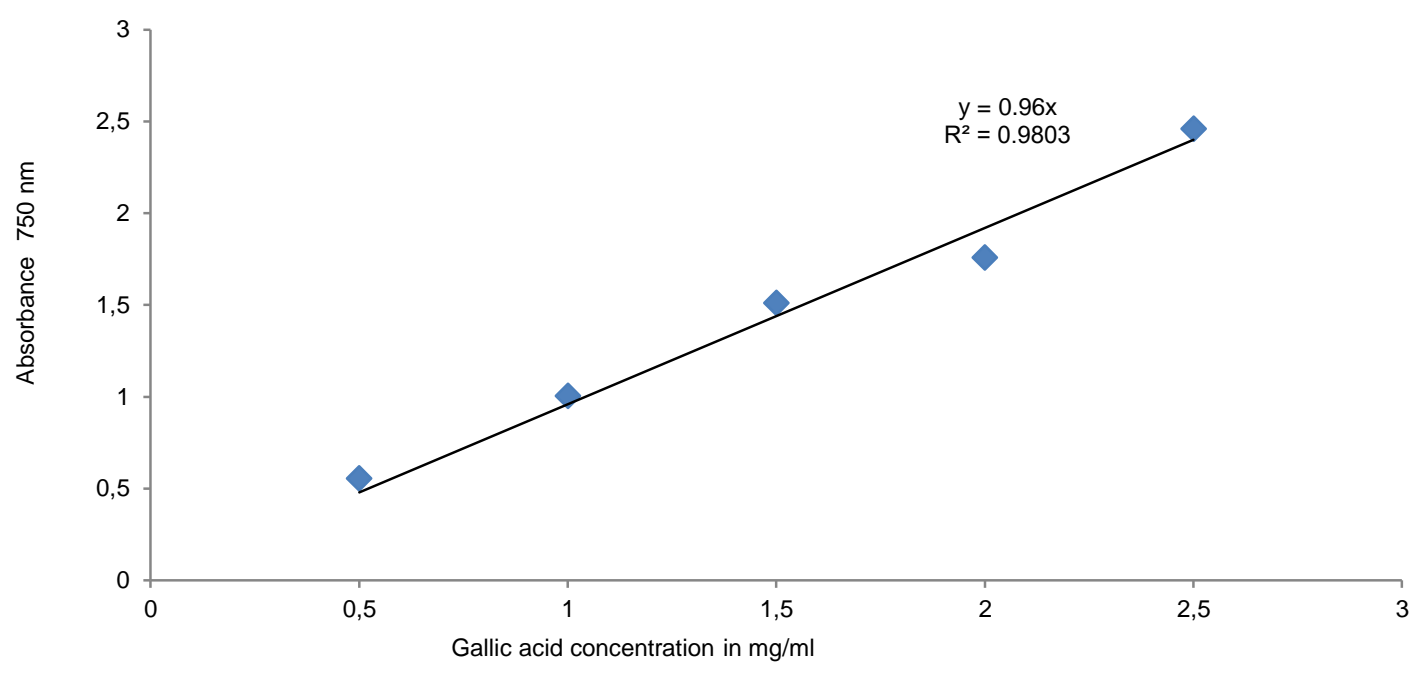

Figure 5 Standard curve of total phenolic content estimation with gallic acid.

Table 1 Total phenolic content profile of the aqueous methanol extracts of Carica papaya seeds flour, defatted flour, protein concentrates and protein isolates

\begin{tabular}{l|ccccc}
\hline \multirow{2}{*}{ Samples } & \multicolumn{5}{|c}{ Concentration in GAE $\mu \mathrm{g} / \mathrm{g}$} \\
\cline { 2 - 6 } & 0.5 & 1.0 & 1.5 & 2.0 & 2.5 \\
\hline CFF & $0.245 \pm 0.01^{\mathrm{b}}$ & $0.432 \pm 0.01^{\mathrm{c}}$ & $0.611 \pm 0.01^{\mathrm{c}}$ & $0.630 \pm 0.01^{\mathrm{c}}$ & $0.748 \pm 0.01^{\mathrm{bc}}$ \\
$\mathrm{CDF}$ & $0.359 \pm 0.01^{\mathrm{a}}$ & $0.644 \pm 0.01^{\mathrm{a}}$ & $0.677 \pm 0.01^{\mathrm{a}}$ & $0.738 \pm 0.01^{\mathrm{a}}$ & $0.810 \pm 0.01^{\mathrm{a}}$ \\
CPC & $0.160 \pm 0.02^{\mathrm{dd}}$ & $0.501 \pm 0.01^{\mathrm{b}}$ & $0.658 \pm 0.03^{\mathrm{ab}}$ & $0.708 \pm 0.01^{\mathrm{ab}}$ & $0.761 \pm 0.01^{\mathrm{b}}$ \\
CPI & $0.148 \pm 0.01^{\mathrm{d}}$ & $0.294 \pm 0.01^{\mathrm{d}}$ & $0.557 \pm 0.01^{\mathrm{d}}$ & $0.602 \pm 0.01^{\mathrm{cd}}$ & $0.721 \pm 0.01^{\text {bcd }}$ \\
\hline
\end{tabular}

Data are means \pm SD $(\mathrm{n}=5)$. Mean values with different superscript within the column are significantly $(\mathrm{P}<0.05)$ different. CFF: Full-fat flour of Carica papaya seeds, CDF: Defatted flour of Carica papaya seeds, CPC: Protein concentrates of Carica papaya seeds, CPI: Protein isolate of Carica papaya seeds

Table 2 Total phenolic content profile of the absolute methanol extracts of Carica papaya seeds flour, defatted flour, protein concentrates and protein isolates

\begin{tabular}{l|ccccc}
\hline \multirow{2}{*}{ Samples } & \multicolumn{5}{|c}{ Concentration in GAE $\mu \mathrm{g} / \mathrm{g}$} \\
\cline { 2 - 6 } & 0.5 & 1.0 & 1.5 & 2.0 & 2.5 \\
\hline CFF & $0.191 \pm 0.01^{\mathrm{cd}}$ & $0.200 \pm 0.03^{\mathrm{c}}$ & $0.238 \pm 0.01^{\mathrm{c}}$ & $0.321 \pm 0.01^{\mathrm{c}}$ & $0.453 \pm 0.01^{\mathrm{c}}$ \\
CDF & $0.245 \pm 0.01^{\mathrm{a}}$ & $0.417 \pm 0.01^{\mathrm{a}}$ & $0.481 \pm 0.01^{\mathrm{a}}$ & $0.548 \pm 0.01^{\mathrm{a}}$ & $0.675 \pm 0.01^{\mathrm{a}}$ \\
CPC & $0.142 \pm 0.01^{\mathrm{b}}$ & $0.244 \pm 0.01^{\mathrm{b}}$ & $0.286 \pm 0.01^{\mathrm{b}}$ & $0.424 \pm 0.01^{\mathrm{b}}$ & $0.502 \pm 0.01^{\mathrm{b}}$ \\
CPI & $0.131 \pm 0.01^{\mathrm{d}}$ & $0.169 \pm 0.01^{\mathrm{d}}$ & $0.226 \pm 0.01^{\mathrm{d}}$ & $0.281 \pm 0.01^{\mathrm{d}}$ & $0.373 \pm 0.01^{\mathrm{d}}$ \\
\hline
\end{tabular}

Data are means \pm SD $(n=5)$. Mean values with different superscript within the column are significantly $(\mathrm{P}<0.05)$ different. CFF: Full-fat flour of Carica papaya seeds, CDF: Defatted flour of Carica papaya seeds, CPC: Protein concentrates of Carica papaya seeds, CPI: Protein isolate of Carica papaya seeds 


\section{Effect of $\mathrm{pH}$ on the Yield of Protein Isolate}

The yield of protein isolates ranged from 53.34$88.08 \%$ of the starting material (CPS flour) as a function of the $\mathrm{pH}$ range applied for protein precipitation $(\mathrm{pH} 4.0$ 10.0). The yields of all CPS protein isolate samples were significantly lower than that of safflower protein isolates. It was mainly due to substantially higher protein contents in the safflower flour than the CPS flour. The protein isolate yield could be increased by different techniques such as repeating the extraction process (Kiosseoglou et al., 1999), increasing the $\mathrm{pH}$ of the extracting solution to 11 or 12 (Lqari et al., 2002; Ruiz and Hove, 1976), using extraction aids such as $\mathrm{Na}_{2} \mathrm{SO}_{3}$ (Sanchez-Vioque et al., 1999) or using various precipitating aids such as sodium hexametaphosphate, sodium sulphate (Jayasena et al., 2006; Ruiz and Hove, 1976) and sodium hydroxide $(\mathrm{NaOH})$. Nevertheless, all these practices incur an additional cost and could result in deterioration of the functional properties which may not be feasible technically and economically. In the case of using higher $\mathrm{pH}$ for extraction or repeating the extraction step, a higher volume of acid will be required to lower the $\mathrm{pH}$ of the protein suspension during the acid precipitation step. Another major shortcoming of the application of extreme alkaline $\mathrm{pH}$ is protein denaturation. The subsequent inferior quality will limit the applications of such protein in the food industry.

\section{Total Phenolic Content (TPC)}

Phenolic compounds are considered as a major group of organic compounds that contribute to the antioxidant potential of cereals (Liu and Yao, 2007). The highest TPC was extracted with the aqueous methanol compared to absolute methanol extract. This observation compares well with the findings of Liu and Yao (2007) and Farooq et al. (2010). Aqueous methanol is known to be an efficient and widely used solvent system for the extraction of natural antioxidant components, especially phenolic compounds from plant materials (Farooq et al., 2010). The higher polarity of methanol-water mixtures might be a reason for the greater efficacy towards extraction of polar phytochemicals such as phenolic and flavonoids as reported by Siddiq et al. (2005). A Strong positive correlation exists between the TPC and extracts concentration (Table 4) when compared to TPC and protein concentration.

The result obtained in this study revealed that the CDF for both the absolute and aqueous extract have the highest total phenol contents $(0.675 \mu \mathrm{g}$ GAE/g and $0.810 \mu \mathrm{g}$ $\mathrm{GAE} / \mathrm{g})$ and was significantly $(\mathrm{P}<0.05)$ higher than values gotten for the CFF, CPC and CPI of both aqueous and absolute extract, respectively. The low phenolic content of the protein isolate might be as a result of the loss of iso-flavones associated with soluble compounds, mainly proteins during extraction due to modification of the protein molecular charge and conformation, since proteins are extracted at alkaline $\mathrm{pH}$ an observation which compares well with the findings of Wang and Murphy (1994) on the iso-flavones of commercial soybean. The significant amount of phenolic compound present in the samples gives an advantage to them for use as antioxidants.

\section{Correlation between Total Phenolic Content (TPC),}

\section{Protein Concentration and Extract Concentration}

The relationships between the total phenolic and protein concentration of all samples were evaluated using Pearson correlation test. A best fit straight regression line was plotted with a coefficient of determination, $\mathrm{R}^{2}=$ 0.6247 and 0.6374 for a linear correlation between total phenolic content and protein concentration and $\mathrm{R}^{2}=$ 0.9502 and 0.9757 for a linear correlation between total phenolic content and extracts concentration (Figure 6), respectively. As illustrated in Figure 6, there was a strong positive correlation $(r=0.988$ and $r=0.975)$ between the phenolic content and extracts concentration for the methanolic and aqueous methanolic extracts, respectively. The points in Figure $6 \mathrm{~b}$ for these variables follow the line closely suggesting that there exists a strong relationship between them. However, the data points for the linear correlation between the total phenolic content and protein concentration appear to be randomly distributed. The majority of the points shown in Figure 6a do not fall close to the line, indicating a very weak relationship if one exists. The Pearson coefficient for this relationship is + 0.798 and +0.790 .
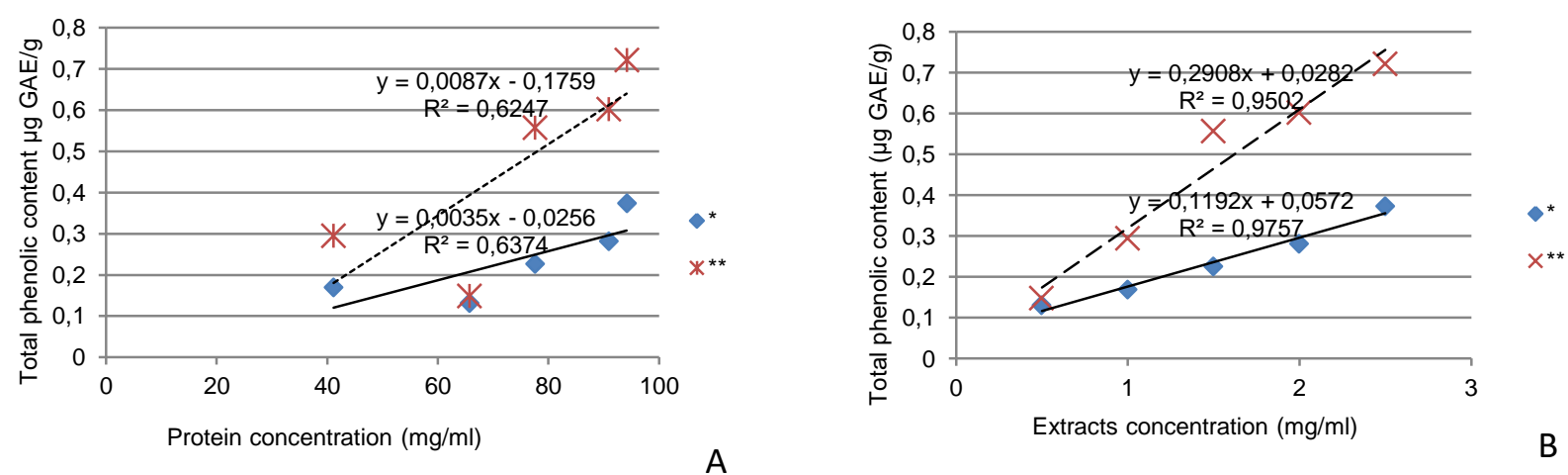

Figure 6 Correlation between the total phenolic content ( $\mu \mathrm{g} \mathrm{GAE} / \mathrm{g}$ ) measured with aqueous or methanolic extracts with protein concentration $(\mathrm{mg} / \mathrm{ml})$ and extracts concentration $(\mathrm{mg} / \mathrm{ml}), *$ Absolute methanol extracts, **Aqueous methanol extracts 
Table 3 r-values of Pearson correlation test

\begin{tabular}{c|cc}
\hline Experimental Factors & \multicolumn{2}{|c}{ Total phenolic content $(\mu \mathrm{g}$ GAE/g) } \\
\cline { 2 - 3 } & Methanolic extract & Aqueous methanolic extract \\
\hline Protein concentration $(\mathrm{mg} / \mathrm{ml})$ & 0.798 & 0.790 \\
Extract concentration $(\mathrm{mg} / \mathrm{ml})$ & 0.988 & 0.975 \\
\hline
\end{tabular}

\section{Conclusion}

It can be concluded base on the study that the processed CPS products comprising of the defatted flour, protein concentrate and protein isolate contain appreciable amount of phenolic compounds, and aqueous methanol was the best solvent for the extraction of phenolic compounds. CPS protein isolates containing high protein content of above $88.08 \%$ with the potential to replace soy protein isolate as a new, low-cost source of vegetable protein, can be prepared by using a simple method. A protein isolate with similar protein content and yield can be produced at a higher $\mathrm{pH}$ point (for example $\mathrm{pH} 9.0$ 10.0) which will reduce the volume of acid required for the precipitation of protein, thus reducing the production cost of protein isolates. Reduced acid utilization will also help reduce environmental pollution. Other properties such as the color of the protein isolate and in-vivo antioxidant assay of the flour products/isolate may be important and could be considered for future studies.

\section{Acknowledgement}

The authors are indebted to the staff at the food chemistry laboratory, Department of Food Science and Technology, Obafemi Awolowo University Nigeria for their valuable guidance and help in protein isolation and chemical analysis.

\section{References}

Alireza SM, Bhagya S. 2009. Effect of recovery method on a different property of the mustard protein. World Journal of Dairy \& Food Sciences, 4,100-106.

Chavan U, Mckenzie D, Shahidi F. 2001. Functional properties of protein isolates from beach pea (Lathyrus maritimus L.). Food Chem 74: 177-187.

Cheftel JC, Cuq JL, Lorient D.1985. Food Chemistry: Amino acids, peptides and proteins (edited by Fennema, O. R.). New York, NY: Marcel Dekker. pp. 127-228.

Dwikat M, Dini L. Antioxidant effect of aqueous Carica papaya seed extract. 2nd Conference on Biotechnology Research and Applications. 26-27 September 2010, An-Najah National University, Nablus, Palestine.

Eltayeb AS, Abou-Arab AA, Ali OA \& Abu-Salem FM. 2011 Chemical composition and functional properties of flour and protein isolate extracted from Bambara groundnut (Vigna subterranean). African Journal of Food Science, 5(2), 82 - 90

Farooq A, Hafiz MAQ, Abdullah IH, Shahid I. 2010. Antioxidant activity of $100 \%$ and $80 \%$ methanol extracts from barley seeds (Hordeum vulgare L.): stabilization of sunflower oil. Grasasy Aceities (6) $13: 237-243,2010$.

Gbadamosi SO, Abiose, SH, Aluko, RE. 2012. Amino acid profile, protein digestibility, thermal and functional properties of Conophor nut (Tetracarpidium conophorum) defatted flour, protein concentrate and isolates. Inter J. Food Sci Tech 47: 731739.
Gulcin I, Oktay M, Kirecci E, Kufrevioglu, OI. 2003. Screening of antioxidant and antimicrobial activities of anise (Pimpinella anisum L.) seed extracts. Food Chem 83: 371.

Iyawe HOT, Azih MC. 2011. Total phenolic contents and lipid peroxidation potentials of some tropical antimalarial plants. Eur. J. Med Plants 1(2): 33-39.

Jaime SAT, Rashid Z, Nhut DT, Sivakumar D, Gera A, Manoel TS, Tennant PF. 2007. Papaya (Carica papaya L.) Biology and Biotechnology. Tree and Forestry Science and Biotechnology $1(1): 47-73$

Jayasena V, Chih, HJ \& Dods K. 2006. Precipitation pH vs. yield and functional properties of lupin protein isolate. Agribusiness Crop Updates.

Kadiri O, Olawoye B. 2016. Vernonia amygdalina: An underutilized vegetable with nutraceutical Potentials - A Review. Turkish Journal of Agriculture - Food Science and Technology, 4(9): 763-768.

Kadiri O. 2015. Studies on the chemical composition, functional and antioxidant properties of Carica Papaya (Pawpaw) seed flour, protein concentrate and protein. M.sc thesis. Department of Food Science and Technology, Obafemi Awolowo University, Ile-Ife, Nigeria.

Kadiri O, Olawoye B. 2015. Underutilized indigenous vegetable (UIV) In Nigeria: A richsSource of nutrient and antioxidants- A Review. Annals. Food Science and Technology, 16(2): 236-247.

Kain JR, Che Z, Sonda ST \& Abu-kpawoh JC. 2009. Study on the effects of enzymatic hydrolysis on the physical, functional and defatted heat pressed meal flour (Arachis hypogaea L.). Pakistan Journal of Nutrition, 8,818-825.

Kiosseoglou A.1999. Physical characterization of thermally induced networks of lupin protein isolates prepared by isoelectric precipitation and dialysis. International Journal of Food Science Technology 34: 253-263.

Liu Q, Yao H. 2007. Antioxidant activities of barley seeds extracts. Food Chem 102, 732-737.

Lqari H. 2002. Lupinus angustifolius protein isolates: chemical composition, functional properties and protein characterization. Food Chem. 76: 349-356.

Markwell MAC, Haas SM, Biebar LL, Tolbert, NE. 1978. A modification of the Lowry procedure to simplify protein determination in membranes and in protein samples. Analy Biochem 87: 206-211.

Oloyede O, Roos D, Rocha J. Studies on the Antioxidant Potential of Extracts from Unripe Fruit of Carica papaya. J. Life Sci 2012; 6:41-47.

Pierson JT, Dietzgen RG, Shaw PN, Roberts-Thomson SJ, Monteith GR, Gidley MJ.2012. Major Australian tropical fruits biodiversity: bioactive compounds and their bioactivities. Molec Nut \& Food Res 56: 357-87

Quan V, Vuong, SH, Paul D, Roach MC, Bowyer, Phoebe A, Phillips, Christopher J. Scarlett . 2013. Effect of extraction conditions on total phenolic compounds and antioxidant activities of Carica papaya leaf aqueous extracts. J Herb Med 3; 104-111.

Ruiz LP, Hove EL .1976. Conditions affecting production of a protein isolate from lupin seed kernels. 27(7): 667-674.

Sanchez-Vioque R.1999. Protein isolates from chickpea (Cicer arietinum L.): chemical composition, functional properties and protein characterization. Food Chem. 64: 237-243. 
Sathe, SK. 1994. Solubilization and electrophoretic characterization of cashew nut (Anacardium occidentale) proteins. Food Chem 51: 319-324.

Siddiq A, Anwar F, Manzoor M, Fatima M. 2005.Antioxidant activity of different solvent extracts of Moringa oleifera leaves under accelerated storage conditions of sunflower oil. Asian J. Plant Sci. 4, 630-635.

Singleton VL, Rossi JA. 1965. Colorimetry of total phenolic with phosphomolybdic phosphotungstic acid reagents. Am J. Enolo Viticult 16: 144-158.

Tsao R. 2010. Chemistry and biochemistry of dietary polyphenols. Nutr 2: 1231-46.

Visioli F, De La Lastra CA, Andres-Lacueva C, Aviram M, Calhau C, Cassano A. 2011.Polyphenols and human health: a prospectus. Crit Rev Food Sci Nut ;51:524-46.
Ulloa AJ, Rosas-Ulloa P \& Ulloa-Rangel BE. 2011. Physicochemical and functional properties of a protein isolate produced from safflower (Carthamus tinctorius L.) meal by ultrafiltration. Journal of Science of Food and Agriculture, 91, 572-577.

Vuong QV. Epidemiological evidence linking tea consumption to human health: a review. 2012. Crit Rev Food Sci Nut. http://dx.doi.org/10.1080/ 2011.594184.

Wang H. J. and Murphy, PA. 1994. Isoflavone content in commercial soybean foods. Journal of Agricultural and Food Chemistry. 42 (8): 1666-1673.

Yu-Wei L, Wang Q. 2015. Effect of processing on phenolic content and antioxidant activity of four commonly consumed pulses in China. J Horticulture 2: 130. doi:10.4172/2376-0354.1000130

Zhou KB, Wang H, Mei WL, Li X, Luo Y, Dai HF. Antioxidant activity of papaya seed extracts. Mole 16 (8): 6179-6192. 